УДК 342.92

DOI https:/ / doi.org/10.32837/yuv.v0i2.1738

Ю. Буланова,

здобувач кафедри адміністративного та господарського права

Запорізького національного університету

\title{
НАПРЯМИ ЗАБЕЗПЕЧЕННЯ ПРАВОВОЇ ЕФЕКТИВНОСТІ ЕТИЧНИХ КОДЕКСІВ У РЕГУЛЮВАННІ СЛУЖБОВИХ ВІДНОСИН
}

Сучасні реалії характеризують активізацію діяльності 3 необхідності гармонізації системи національного законодавства України відповідно до визначених загальноєвропейських стандартів забезпечення реалізації та захисту прав та інтересів людини i громадянина. Триваюча трансформаційна діяльність із гармонізації системи національного законодавства України характеризується формуванням та становленням унікальних міжгалузевих правових конструкцій, формуванням прогресивних уявлень про систему права відповідно до існуючих реалій. Адміністративне право України при цьому визначається як галузь права, що зазнає найбільших трансформаційних впливів, пов'язаних із необхідністю переосмислення його предмету, функцій, структури системи та їі складників. Забезпечення ефективності реалізації етичних кодексів пов'язується із застосуванням механізму юридичної відповідальності у разі недотримання чи порушення етичних норм та стандартів, зокрема заходів дисциплінарної чи адміністративної відповідальності.

Сучасна правова доктрина застосовує два підходи до розуміння сутності дисциплінарної відповідальності: негативний (або ретроспективний) та позитивний. Прихильниками ретроспективного підходу (С.Н. Братусь, О.С. Іоффе, Р.О. Халфіна, Л.С. Явич та ін.) категоріальна сутність поняття юридичної відповідальності трактується крізь призму реалізації заходів державного примусу та покарання за вчинення пра- вопорушення. Таким чином, юридична відповідальність $€$ зовнішньою реакцією держави на прояви протиправної відповідальності за умови застосування ретроспективного підходу у разі його правозастосування.

Метою наукової статті $€$ визначення напрямів забезпечення правової ефективності етичних кодексів у регулюванні службових відносин.

У межах ретроспективного підходу до визначення сутності юридичної відповідальності вартою уваги є позиція, висловлена у наукових розробках Г.В. Задорожної. Вченою підкреслювалася необхідність розуміння юридичної відповідальності як сукупності негативних наслідків, обмежень, що настають для особи у разі недотримання нею вимог чинного законодавства чи договору. Г.В. Задорожна обгрунтовувала таку позицію в тому числі неможливістю лексичного поєднання термінів «позитивна» та «відповідальність»: науковцем підкреслювався негативний характер обмежень, що мають застосовуватися до особи, лише у такий спосіб $є$ можливим досягнути реалізації соціальних норм у цілому і зокрема норм права як складників їх системи [1, с. 108].

Позитивний підхід натомість ураховує як зовнішній вплив держави (в особі спеціально уповноважених органів) та суспільства на особу правопорушника, так і на свідоме розуміння особою правопорушника протиправності вчиненого і сприяння усуненню заподіяних збитків. Серед учених, що обстою- 
ють такий підхід до розуміння сутності та характеру юридичної відповідальності, можна відзначити M.I. Матузова, А.В. Малько [2], Т.О. Коломоєць [3], Ю.О. Легези [4], А.Т. Комзюка [5], M.I. Смоковича [6] та ін. Реалізація позитивного підходу дає змогу визначити юридичну відповідальність як здатність, свідоме розуміння суб'єкта на виконання певних дій та реалізацію завдань, що висуваються перед ними, тобто свідоме неухильне дотримання особою покладених на неї обов'язків. $\mathrm{y}$ межах даного дослідження категорія «юридична відповідальність» розглядатиметься із застосуванням позитивного підходу, що дає змогу врахувати не лише об'єктивний чинник впливу на особу правопорушника, а й суб'єктивний підхід до усвідомлення негативних наслідків учиненого діяння.

Спроба застосувати інтегративний підхід до розуміння категорії «юридична відповідальність» здійснена у наукових розробках Н.В. Заяць. Ученою відзначався діалектичний зв'язок позитивного та негативного розуміння юридичної відповідальності, при цьому підкреслювалося, що лише в умовах досягнення належного рівня позитивного впливу на особу правопорушника рідше виникає необхідність застосування негативного (ретроспективного) втручання. Окрім того, виконання покладених на особу обов'язків, ефективність їх реалізації за своїм рівнем правового застосування $є$ вищою у разі свідомого розуміння особи щодо безумовної доцільності такої форми своєї діяльності [7, с. 80-81]. Такий підхід $€$ найбільш актуальним у разі необхідності оптимізації правового регулювання службових відносин, забезпечення реалізації іï етичного складника.

$\mathrm{y}$ цілому загальнотеоретичний підхід до розуміння категорії «юридична відповідальність» зводиться до виділення такої іiі безумовної ознаки, як нерозривність зв'язку 3 учиненням правопорушення та необхідністю застосування заходів державного примусу [8, с. 42-43].
Н.А. Берлач відзначає, що під категорією «відповідальність» необхідно розуміти визначену реакцію держави на діяння особи, що суперечить установленим вимогам чинного законодавства чи договору [9, с. 79].

В умовах розвитку сучасної юридичної науки не визначено усталених підходів до розуміння категорії «дисциплінарна відповідальність». Вартим уваги $є$ підхід, вироблений Д.М. Овсянко, що підкреслює необхідність для ефективної реалізації заходів дисциплінарної відповідальності встановлення наявності службового підпорядкування між особою-порушником та правозастосувачем [10, с. 43]. Широке тлумачення категорії дисциплінарної відповідальності запропоноване в межах науки трудового права, зокрема такими ії представниками, як M.I. Іншин та A.P. Мацюк, які відзначили, що під дисциплінарною відповідальністю розуміється застосування заходів дисциплінарного впливу на учасників трудоправових відносин [11, с. 730]. За підходом, обгрунтованим О.В. Нікіфоровим, установлено, що дисциплінарна відповідальність розглядається як обов'язок особи нести покарання, що застосовується у разі вчинення особою порушення встановлених норм та стандартів службової дисципліни [12, с. 10].

Ототожнення категорій «дисциплінарна відповідальність» та «заходи дисциплінарного впливу» відбувається у межах здійснених О.Ф. Ноздрачовим наукових досліджень [13, с. 503-505], що підтримано низкою інших представників юридичної науки, зокрема, Г.С. Івановою $[14$, с. 163-168] та Г.Г. Петришиною-Дюг [15, с. 39-43]. Зокрема, Г.Г. Петришина-Дюг наголошує на необхідності розуміння дисциплінарної відповідальності як обов'язку працівників зазнати певних утрат особистого характеру за вчинення дисциплінарного проступку, передбаченого нормами трудового законодавства [15, с. 39-40]. До засобів трудового регулювання відносить механізм застосування дисциплінарної відповідаль- 
ності О.В. Родіонова; вченою визначається доцільність реалізації заходів державного примусу в разі невиконання трудового обов'язку учасником відповідних правовідносин [16, с. 107].

Т.О. Коломоєць під дисциплінарною відповідальністю у широкому значенні розуміє гарантію забезпечення зміцнення службової дисципліни, запобігання проявам корупції, дисциплінарних проступків, при цьому вченою визначається як підстава до іiі застосування вчинення порушень правил внутрішнього розпорядку підприємства, установи, організації [3, с. 157].

Досліджуючи проблеми забезпечення ефективності застосування заходів дисциплінарної відповідальності, В.В. Доненко відзначає пріоритетність владно-розпорядчих методів правового регулювання такої сфери суспільних відносин, що $є$ найбільш характерним, вочевидь, для адміністративно-управлінських зв'язків [17, с. 120]. Окрім того, В.К. Колпаков та В.В. Доненко наголошують на поглинаючому характері адміністративних і дисциплінарних стягнень, що в службових правовідносинах свідчить про необхідність ї поєднання [17, с. 120-122].

$\mathrm{У}$ цілому, розуміючи прогресивність такого підходу, в межах даного дослідження є необхідним визначити критерії відмежування адміністративної та дисциплінарної відповідальності як гарантій забезпечення правової ефективності регулювання службових правовідносин. Критеріями розмежування адміністративної та дисциплінарної відповідальності необхідно визначити: правозастосовчі органи (у разі вчинення адміністративного делікту до особи правообмежуючі заходи застосовує орган, з яким порушник не перебуває у трудових чи службово-трудових правовідносинах); характер правообмежувальних наслідків (у разі застосування заходів дисциплінарної відповідальності відносно особи-порушника застосовуються стягнення, характер та сутність яких створює перешкоди для просування по службі чи вза- галі позбавляє особу права обіймати певні посади; у разі вчинення адміністративного делікту такий наслідок $є$ похідним та факультативним (тобто таким, що виникає лише через учинення визначеного різновиду правопорушення (зокрема, таким є корупційне чи корупціогенне правопорушення)). Безумовним критерієм відмежування механізмів дисциплінарної та адміністративної відповідальності $€$ підстава та процедура їх застосування. Зокрема, характер дисциплінарно-деліктного провадження свідчить про неоднозначність та законодавчу неврегульованість процедур його реалізації на відміну від адміністративно-деліктного провадження.

Реалізація заходів дисциплінарного впливу має відповідати таким універсальним правовим принципам правозастосування, як законність, обгрунтованість, доцільність, справедливість, пропорційність обмеження, гласність, невідворотність та персоніфікація впливу [8, с. 48]. До спеціальних принципів застосування заходів дисциплінарної відповідальності О.Д. Новак відносить оперативність реалізації відповідних стягнень, презумпцію невинуватості [18, с. 264-268].

Окрім заходів обмежувального впливу, що є складовою частиною механізму юридичної відповідальності, позитивне розуміння останньої передбачає застосування заохочень. Застосування заохочень у сфері публічної служби дає змогу вирішити низку стратегічних державницьких завдань, оптимізувати діяльність із реалізацій функцій держави, що становить зміст професійної компетентності функціонування органів державної влади та місцевого самоврядування. Пріоритетним завданням, що достатньо ефективно вирішується у разі оптимізації застосування заохочення як стимулювання сумлінного виконання службових обов'язків, $€$ забезпечення високої оцінки діяльності публічного службовця та його переконання у «корисності» відповідального, гідного ставлення до виконання 
покладених на нього обов'язків та реалізації наданих йому прав.

Ефективність впливу системи засобів заохочення на особу публічного службовця базується на існуючій, відповідно до системи А. Маслоу, потреби кожної людини у визнанні [19, с. 133134; 20, с. 70-73]. Спираючись на досягнення психологічної та соціологічної науки, заохочення мають позитивний вплив на внутрішній світ людини, сприяють реалізації публічним службовцем його суб'єктивних, насамперед нематеріальних, потреб. Досягнення такого висновку дає змогу обгрунтувати взаємозв'язок заохочення 3 емоційно-психологічною сферою особистості, що визначає обов'язок уповноважених владних суб'єктів до забезпечення ефективності вирішення питання заохочення службової діяльності та їі результатів. Аргументацією необхідності забезпечення ефективності системи заохочень є, крім зазначеного, необхідність запобігання тяжким емоційним наслідкам службовців, що може бути наслідком за відсутності реалізації функції стимулювання сумлінності виконання покладених на особу службових обов'язків.

Варто відзначити, що з урахуванням вищезазначеного поєднання ретроспективного та позитивного підходів до розуміння категорії «юридична відповідальність» у цілому і зокрема дисциплінарної відповідальності як іiі різновиду нехтування засобами заохочення та стимулювання як факторами забезпечення ефективності реалізації етичних норм $€$ недоцільним і таким, що суперечить концепціï good governance (концепції публічного прозорого, відкритого управління).

Отже, заходи заохочення, підстави їх застосування розглядаються як гарантії забезпечення належності й ефективності реалізації норм етичних кодексів, як складова частина механізму позитивної юридичної відповідальності публічних службовців.

3 урахуванням значення та ролі заходів заохочення у системі право- вого регулювання проходження публічної служби вони, так само як і заходи юридичної відповідальності службовців, мають визначатися на законодавчому рівні. Низький рівень вирішення такого завдання правового регулювання публічної служби визначається фрагментарністю регулювання застосування заходів заохочення. Варто підкреслити, що заохочення, їх застосування не повинні стати засобом зловживання службовим становищем. Зокрема, постає питання: чи можливо розглядати визначення розміру призначення премій на посаді як засіб заохочення чи як спосіб зловживання службовим становищем? Фрагментарність та підзаконність правового регулювання застосування засобів заохочення у службовій діяльності вимагає пошуку напрямів вирішення такої проблеми, адже іi подолання своїм результатом буде мати, безумовно, підвищення ефективності виконання працівниками публічної служби покладених на них службових обов'язків.

Статтю присвячено визначенню напрямів забезпечення правової ефективності етичних кодексів у регулюванні службових відносин. Автором визначено необхідність здійснення трансформаційних змін структури адміністративного права, що обгрунтовується необхідністю вирішення стратегічних завдань, що стоять перед сучасною державою, що полягає в оптимізациї здійснення публічно-управлінської діяльності із забезпечення прав та свобод людини, що визначається як складова частина предмету науки адміністративного права. Метою наукової статті $\epsilon$ визначення напрямів забезпечення правової ефективності етичних кодексів у регулюванні службових відносин. Автором підкреслено, щз реалізація позитивного підходу дає змогу визначити юридичну відповідальність як здатність, свідоме розуміння суб'єкта на виконання певних дій та реалізацію завдань, 
що висуваються перед ними, тобто свідоме неухильне дотримання особою покладених на неї обов'язків. У межах даного дослідження категорію «юридична відповідальність» визначено із застосуванням позитивного підходу, шо дало змогу врахувати не лище об'єктивний чинник впливу на особу правопорушника, а й суб'єктивний підхід до усвідомлення негативних наслідків учиненого діяння. У статті підкреслено, шо вирішення завдання досягнення наленного рівня правової ефективності застосування заходів дисциплінарної відповідальності та засобів заохочення $\epsilon$ складником механізму забезпечення належного рівня правової реалізації етичних норм у регулювання відносин публічної служби. Як висновок обгрунтовано необхідність визначення на законодавчому рівні системи заохочення як складової частини правового регулювання проходження публічної служби, так само як $і$ системи заходів дисииплінарної відповідальності службовиців.

Ключові слова: етична поведінка, публічний службовець, нормативно-правові акти, службове право, джерела, професійна етика.

Bulanova Yu. Directions of ensuring the legal effectiveness of codes of ethics in the regulation of relations

The article is devoted to determining the directions of ensuring the legal effectiveness of ethical codes in the regulation of official relations. The author defines the need for transformational changes in the structure of administrative law, substantiates the need to address the strategic challenges facing the modern state, which consists in optimizing the implementation of public management activities to ensure human rights and freedoms, is defined as a component of the subject of science of administrative law. The aim of the scientific article is to determine the directions for ensuring the legal effectiveness of ethical codes in the regulation of official relations. The author emphasizes that the implementation of a positive approach allows us to define legal responsibility as the ability, a conscious understanding of the subject to perform certain actions and the implementation of the tasks put forward before them, that is, a conscious strict observance by a person of the duties assigned to him. In the framework of this study, the category of "legal liability" was determined using a positive approach, which allowed taking into account not only the objective factor of influence on the personality of the offender, but also the subjective approach to understanding the negative consequences of the committed act. The article emphasizes that the solution to the problem of achieving the appropriate level of legal effectiveness of the application of disciplinary measures and incentives is an integral part of the mechanism to ensure the proper level of legal implementation of ethical standards in the regulation of public service relations. As a conclusion, it was substantiated that the need to determine at the legislative level a reward system as part of the legal regulation of public service, as well as a system of disciplinary measures for employees.

Key words: ethical behavior, public servant, normative legal acts, official law, sources, professional ethics.

\section{Література}

1. Задорожна Г.В. Щодо конституиійної відповідальності. Право України. 2007. № 9. C. 107-109.

2. Теория государства и права / под ред. Н.И. Матузова и А.В. Малько. Москва: Юрucm, 1997. 742 c.

3. Коломоєиь Т.О. Адміністративне право України. Академічний курс : підручник. Київ : Юрінком-Інтер, 2011. 576 с.

4. Легеза Ю.О. Адміністративна відповідальність за правопорушення у сфері використання природних ресурсів. Право $i$ суспільство. 2017. № 3. С. 140-147.

5. Комзюк А.Т. Деякі проблеми реалізації принципів адміністративної відпові- 


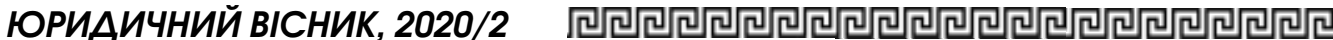

дальності публічних службовців. Публічна служба $і$ адміністративне судочинство: здобутки і виклики : збірник матеріалів I Міннародної науково-практичної конфе ренції, м. Київ, 5-6 липня 2018 р. Київ : Дакор, 2018. С. 180-183.

6. Смокович М.I. Суддівська незалежність та дисииплінарна відповідальність: пошук балансу. Публічна служба $і$ адміністративне судочинство: здобутки $і$ виклики : збірник матеріалів I Міжнародної науково-практичної конференцї, м. Київ, 5-6 липня 2018 р. Київ : Дакор, 2018. C. $373-381$.

7. Заяцьь Н.В. Особливості прояву позитивної конституційно-правової відповідальності в діяльності інститутів народного представництва. Науковий вісник Львівського державного університету внутрішніх справ. 2010. № 2. С. 79-88.

8. Дисциплінарно-деліктне право України : навчальний посібник / T.С. Аніщенко та ін. ; за заг. ред. Т.О. Коломоєиь, B.К. Колпакова та ін. Київ : Iн Юре, 2016. $464 \mathrm{c}$.

9. Берлач H.A. Перспективи розвитку позитивної юридичної відповідальності в демократичному суспільстві. Форум права. 2012. № 1. С. 77-81.

10. Овсянко Д.М. Государственная служба Российской Федерации : учебное пособие. Москва: Юрист, 2003. 192 с.

11. Курс порівняльного трудового права: підручник / M.I. Іншин та ін. Харків, 2011. 980 c.
12. Никифоров А.В. Дисциилинарная ответстенность сотрудников органов внутренних дел: автореф. дис. ... к.ю.н. : 12.00.14. Омск, 1998. $20 \mathrm{c.}$.

13. Ноздрачев А.Ф. Государственная служба : учебник. Москва : Статут, 1999.

14. Іванова Г.С. Принциипи дисцииллінарної відповідальності в трудовому праві. Актуальні проблеми права: теорія і практика. 2013. № 26. С. 163-168.

15. Петришина-Дюг Г.Г. Дисциилінарна відповідальність у трудовому праві: поняття та принципи. Науковий вісник Чернівецького національного університету ім. Юрія Федьковича. Серія «Правознавство». 2008. Bun. 461. C. 39-43.

16. Родионова Е.В. Юридическая ответственость как разновидность социальной ответственности: современные проблемы. Москва : Юрлитинформ, 2011. 148 с.

17. Адміністративне право України: словник термінів / за заг. ред. Т.О. Коломоєиь, В.К. Колпакова. Київ : Iн Юре, 2014. $519 \mathrm{c}$.

18. Новак О.Д. Щодо розуміння принизипів дисииплінарної відповідальності державних службовиів. Право і безпека. 2012. № 3(45). C. 264-268.

19. Исабекова А.А. Иерархическая система потребностей в трудах А. Маслоу. Молодой ученый. 2015. № 1.1(81.1). C. $133-134$.

20. Литвинчук О.В. Взаємозумовленість потреб та людської діяльності. Гілея. Філософські науки. 2019. Bun. 144. С. 70-73. 